\title{
СТАВОВИ О УПОТРЕБИ ПИСАМА НА ТЕРИТОРИЈИ ОПШТИНЕ ШАБАЦ ${ }^{1}$
}

\begin{abstract}
САЖЕТАК
У овом раду анализирају се ставови грађана општине Шабац о употреби ћириличког и латиничког писма. Циљ истраживања јесте да се укаже на ставове у вези са службеном и неслужбеном употребом два писма у савременом српском језику. Истраживање се спроводи на основу анонимне анкете, а добијени резултати треба да покажу да ли се предност у употреби даје једном од писама и који су параметри који утичу на избор писма.
\end{abstract}

КљУЧНЕ РЕЧИ: употреба писма, ћириличко писмо, латиничко писмо, социолингвистика.

\section{1. Уводне напомене}

Писмо, према Бугарском можемо дефинисати као „систем комуникације међу људима путем конвенционалних видљивих знакова нарочито језичких“ (Бугарски 1997: 9-10). Сам термин писмо означава: посебан систем писања (нпр. хијероглифско или алфабетско писмо), облике писања прилагођене појединим језицима (нпр. руска ћирилица или чешка латиница), а, такође, може имати и низ метафоричких или специјализованих значења (нпр. писмо долине Инда, калиграфско, курзивно, Морзеово, женско писмо) (Бугарски 1997: 10-11).

Употреба језика и писма припада и домену језичке политике. Према Милану Шипки, језичка политика је „теоријски фундирана, смишљена и

\footnotetext{
${ }^{1}$ Овај рад настао је као резултат истраживања које је рађено у оквиру курса Опита лингвистика 1: Појмовник и систематизације на основним студијама на Одсеку за српски језик и лингвистику Филозофског факултета у Новом Саду под руководством проф. др Наташе Киш.
} 
институционализована делатност којој је сврха (1) да се, у складу са идеолошким опредељењима и усвојеном општом политиком, прокламовањем начела, утврђивањем конкретних ставова и доношењем меродавних одлука, регулише јавна употреба језика (тачније језика и језичких варијетета) у одређеној друштвеној заједници, односно појединим областима друштвеног живота: администрацији, медијима, судству, школству, војним формацијама и другде), и (2) да се подстакну, начелно усмере и конкретним мерама подрже процеси језичког планирања и језичке стандардизације како би се језик људског колектива коме служи изградио и развио као ефикасан инструмент јавне комуникације и стваралаштва и тако успешно решили проблеми његовог функционисања” (Шипка 2006: 21). У Републици Србији употреба језика и писма прописана у Уставу Републике Србије и Закону о службеној употреби језика и писма као највишим правним актима, а прецизирана је посебним законима и правилницима као што је, на пример, Правилник о саобраћајној сигнализацији, где је прописана употреба писма у саобраћајној сигнализацији.

Веома је важно дефинисати службену и неслужбену, односно јавну употребу језика и направити разлику између њих. Према Бугарском, граница између неслужбене, али јавне и службене употребе језика није лако одредљива и варира зависно од административног устројства, традиција и политичке оријентације дате државе, али се генерално може рећи да је службена употреба онај нарочито важни и меродавни сегмент јавне употребе који на неки начин носи државни печат. То су, пре свега, званични документи државе и њених органа, као и парадржавних институција у администрацији, образовању, судству, медијима и др. Насупрот томе, приватна штампа, предавања, позоришне представе, филмови итд. припадају јавној, али неслужбеној употреби - баш као, на пример, и цедуља са поруком „Одмах се враћам” коју је власник какве радње истакао на вратима (Бугарски 2005: 85).

У Републици Србији Уставом је прописано ћириличко писмо, као писмо у службеној употреби, док се латиничко писмо користи у јавној употреби и није прописано Уставом као службено. Законом о службеној употреби језика и писма („Сл. гласник РС”, БР. 45/91, 53/93, 67/93, 48/94, 101/2005 - др. закон, 30/2010, 47/2018 и 48/2018 - испр.) у члановима 3, 4 и 5 прецизирана је службена употреба ћириличког писма. Према члану 3 , службеном употребом писма, у нашем случају ћириличког, сматра се употреба писма у: 1) усменом и писменом општењу органа и организација међусобно, као и са странкама, односно грађанима; 2) вођењу поступка за остваривање и заштиту права, 
дужности и одговорности грађана; 3) вођењу прописаних евиденција од стране општинских органа и организација које врше јавна овлашћења на територији општине (у даљем тексту: евиденције); 4) издавању јавних исправа, као и других исправа које су од интереса за остваривање законом утврђених права грађана; 5) остваривању права, дужности и одговорности радника из рада или по основу рада.

Службеном употребом језика и писама сматра се и употреба језика и писама при: исписивању назива места и других географских назива, назива тргова и улица, назива органа, организација и фирми, објављивању јавних позива, обавештења и упозорења за јавност, као и при исписивању других јавних натписа. Према члановима 4 и 5, Закона о службеној употреби језика и писма („Сл. гласник РС”, БР. 45/91, 53/93, 67/93, 48/94, 101/2005 - др. закон, 30/2010, 47/2018 и 48/2018 - испр.) прописана је употреба ћириличког и латиничког писма у следећим ситуацијама: 1) Орган, организација и др. субјект може свој натпис да испише, поред ћириличког, и латиничким писмом; 2) саобраћајни знаци и путни правци на међународним и магистралним путевима, називи места и други географски називи исписују се ћириличким и латиничким писмом; 3) саобраћајни знаци и путни правци на другим путевима, називи улица и тргова и други јавни натписи, могу се, поред ћириличког, исписати и латиничким писмом.

Законом о службеној употреби језика и писма („Сл. гласник РС”, БР. 45/91, 53/93, 67/93, 48/94, 101/2005 - др. закон, 30/2010, 47/2018 и 48/2018 - испр.) прописана је и службена употреба латиничног писма, и то према члановима 11, 19 и 20 овог закона, на следећи начин: 1) Јединица локалне самоуправе ће обавезно својим статутом увести у равноправну службену употребу језик и писмо националне мањине уколико проценат припадника те националне мањине у укупном броју становника на њеној територији достиже $15 \%$ према резултатима последњег пописа становништва, најкасније у року од 90 дана од дана утврђивања законом прописаних услова; 2) На подручјима на којима су у службеној употреби и језици националних мањина, називи места и други географски називи, називи улица и тргова, називи органа и организација, саобраћајни знаци, обавештења и упозорења за јавност и други јавни натписи исписују се и на језицима националних мањина; 3) Фирма предузећа, установе и другог правног лица исписује се на српском језику и на језику националних мањина који је у службеној употреби у општини у којој је седиште тог субјекта. 


\section{2. Циљеви и методологија рада}

У овом истраживању бавићемо се писмом као обликом писања прилагођеном одређеном језику, у овом случају српском. Предмет истраживања јесте употреба два писма, ћириличког и латиничког. „һирилица je, по важности, прво и основно српско писмо. Она у српској традицији има и неоспорну симболичку функцију и зато је оправдана њена фаворизација у службеној, јавној, просветној и културној делатности" (Пешикан - Јерковић Пижурица 2010: 15). Латиничко писмо у нашој средини има готово једновековну традицију условљену српско-хрватским језичким заједништвом из којег је настало богато српско наслеђе штампано латиницом (Пешикан Јерковић - Пижурица 2010: 15).

Основни задаци рада јесу да се укаже на неке тенденције у избору једног или оба писма у различитим доменима употребе, односно у различитим формалним и неформалним ситуацијама, као и да се утврде неки од параметара који утичу на избор писма код становника општине Шабац. Важно је напоменути да је прво емпиријско истраживање у вези са употребом два писма урађено на Одсеку за српски језик и лингвистику у Новом Саду. Ради се о истраживању чији су резултати представљени у радовима Иване Антонић и Свенке Савић: Писма у употреби (Антонић - Савић 1987), ${ }^{2}$ Употреба ћирилице и латинице у основним и средњим школама у Новом Саду (Антонић 1987), Употреба писама у приватним видовима комуникаиије (Резултати пилот истраживања у основним и средњим школама у СР Србији) (Антонић 1989). Ово истраживање је потом покренуло бројне расправе о овој теми које до данас трају.

Циљ овог рада јесте да се на примеру ставова испитаника са територије општине Шабац покаже којем се писму даје предност у службеној и неслужбеној јавној и приватној употреби и укаже на одређене тенденције у овој области.

Ставови о употреби писма прикупљани су помоћу анонимне анкете. Укупан број испитаника био је 300, при том су равномерно заступљени припадници и женског и мушког пола. Као један од параметара у анализи

\footnotetext{
2 Поред наведеног рада парцијални резултати излагани су и у: Антонић - Савић 1987; Savić - Antonić 1987; Антонић 1988; Antonić 1989; а целокупни резултати представљени су у Антонић 1989.
} 
узета је у обзир стручна спрема, односно степен образовања испитаника. Највећи број испитаника 153 (51\%) припада групи са средњим образовањем, високу стручну спрему има 135 (45\%), док само основно образовање има 12 (4\%) испитаника.

Анкета садржи три дела. Први део чине питања политомног типа, тј. питања са вишеструким избором и она се односе на стручну спрему, старост и пол. Други део садржи 14 питања такође са вишеструким избором. Три питања из ове групе су отвореног типа и у њима се очекује краћи писани одговор. У трећем делу анкете испитаници су процењивали степен свог слагања или неслагања са 17 понуђених тврдњи. Понуђени одговори на тврдње одговарају Ликертовој петостепеној скали ставова. Анкета је спровођена лицем у лице и онлајн путем, тако што је била прослеђена одређеним групама људи путем друштвених мрежа и различитих комуникационих програма (вајбер, фејсбук месенџер, вотсап и сл). Метод обраде података је статистичка обрада података са фреквенцијом понуђених одговора изражених у процентима.

Најпре су испитаници одговарали на питања груписана према три основна проблема, тј. три основне теме:
1) свакодневна употреба писма;
2) утицај нових технологија на избор писма;
3) ставови о употреби два писма.

Занимало нас је које писмо у свакодневној писаној комуникацији наши испитаници чешће користе. Други круг питања односи се на утицај нових технологија, пре свега савремених начина комуникације на избор и употребу писма. На основу питања из треће групе желели смо да укажемо на симболичку вредност два писма за појединце, али и колектив.

Други део истраживања обухвата 17 понуђених тврдњи у вези са којима су испитаници изражавали степен свог слагања заокруживањем једног од понуђених одговора: 1 - Уопште се не слажем; 2 - Не слажем се; 3 - Свеједно ми је; 4 - Слажем се; 5 - У потпуности се слажем.

\section{3. Резултати и анализа}

На самом почетку треба дефинисати појам ставова о језику. Према Бугарском, ако генерални појам ставова у социјалнопсихолошком смислу 
подразумева опште и сразмерно трајне диспозиције да се на нешто реагује доследно повољно или неповољно, на афективном, когнитивном или акционом плану, онда се ставови према језику могу одредити као одговарајуће вредносне реакције на различите језике и језичке варијетете, а преко њих најчешће и на њихове говорне представнике (Бугарски 1996:103). Такође, одражавајући сложеност и динамику друштвеног живота неке заједнице, ставови према језику који у њој постоје испуњавају више функција: да помогну у когнитивном организовању и представљању друштвеног света у којем живе њени чланови, водећи рачуна и о ширим системима вредности; да допринесу утврђивању сопственог групног идентитета насупрот другим групама; да олакшају постизање жељених циљева; да прикрију властите слабости; да изазову подозрење према другима, итд. (Бугарски 1996:103). Одлучили смо се да у овом истраживању покушамо да на примеру ставова испитаника са територије општине Шабац уочимо да ли постоји формиран позитивни или негативни однос према употреби ћириличког или латиничког писма, што може имати важности у креирању језичке политике.

Најпре је посматрана свакодневна употреба писма. Намера нам је била да видимо које ће од два писама, ћириличко или латиничко, бити у употреби у одређеним животним ситуацијама (нпр. потписивање, попуњавање налога за уплату и сл.). Следе питања која су испитаницима постављена као и одговори које смо добили изражени у процентима. ${ }^{3}$

- Којим писмом свакодневно пишете?

Ћириличким писмом: 52\%; Латиничким писмом: 26\%; Оба подједнако: $22 \%$

- Којим писмом се служите када попуњавате налог за уплату?

Ћириличким писмом: 71\%; Латиничким писмом: 29\%

- Којим писмом се потписујете?

Ћириличким писмом: 81\%; Латиничким писмом: 19\%

\footnotetext{
${ }^{3}$ На исти начин биће представљена питања и резултати до којих смо дошли у првом делу истраживања.
} 
Затим смо желели да утврдимо колики је утицај нових комуникацијских технологија на избор писма. Када се говори о савременим системима комуникације, конкретно се мисли на утицај, пре свега, друштвених мрежа на интернету, као и на употребу мобилних телефона помоћу којих се може комуницирати путем СМС порука.

- Којим писмом се служите када пишете СМС поруку?

Ћириличким писмом 12\%; Латиничким писмом: $88 \%$

На питање „Зашто?”, испитаници су најчешће наводили да се опредељују за латиницу првенствено због нужности подешавања телефона и тастатуре ако се бира ћирилица, али и да то раде из навике коју су стекли пре него што је употреба ћирилице била могућа у овим ситуацијама.

- Којим писмом се служите на друштвеним мрежама?

Ћириличким писмом: 14\%; Латиничким писмом: $86 \%$

- Да ли сте знали да на друштвеним мрежама, попут латиничног, можете користити и ћирилично писмо?

Да: $84 \%$; Не: $16 \%$

- Уколико је одговор на претходно питање Да, шта утиче на Ваш избор?

Најчешћи одговори на ово питање били су: комуникација са странцима, навика и потреба да се посебно подешава телефон и тастатура ако се бира ћирилица.

На основу треће групе питања желели смо да утврдимо да ли испитаници примећују писмо на којем је нешто написано, што би био могући показатељ важности писма, тј. његове симболичке вредности за испитанике.

- Којим писмом су исписане таблице на превозним средствима?

Ћириличким писмом: 5\%; Латиничким писмом: 79\%; На оба писма: 10\%; Нисам сигуран/на: 6\%

- Којим писмом су исписани саобраћајни знащи , обавештења“?

Ћириличким писмом: 18\%; Латиничким писмом: 28\%; На оба писма: $25 \%$; Нисам сигуран/на: $29 \%$ 
- Којим писмом су исписане табле са називима насељених места?

Ћириличким писмом: 32\%; Латиничким писмом: 6\%; На оба писма: 56\%; Нисам сигуран/на: $6 \%$

- Којим писмом су исписане табле са називима образовних институичја? Ћириличким писмом: 50\%; Латиничким писмом: 6\%; На оба писма: 29\%; Нисам сигуран/на: $15 \%$

Други део анкете представљају тврдње, а наши испитаници, као што је већ речено, исказивали су своје мишљење у вези са њима. На основу степена слагања, покушали смо да уочимо саме ставове који су код испитаника формирани у вези са избором писма.

- Премало пажње се посвећује ћириличком писму.

У потпуности се слажем: $40 \% \quad$ Слажем се: $32 \%$

Свеједно ми је: $17 \%$

Уопште се не слажем: 4\% Не слажем се: $7 \%$

- Коришћење оба писма доноси више штете него користи.

У потпуности се слажем: 7\% Слажем се: $7 \%$

Свеједно ми је: $29 \%$

Уопште се не слажем: $36 \% \quad$ Не слажем се: $21 \%$

- Латиничко писмо треба да постане службено писмо у Србији.

У потпуности се слажем: $10 \%$ Слажем се: $4 \%$

Свеједно ми је: $20 \%$

Уопште се не слажем: $47 \%$ Не слажем се: $19 \%$

- Латиничко писмо попут ћириличког представља културно благо ове земље и треба га једнако поштовати и користити као ћириличко.

У потпуности се слажем: $27 \%$ Слажем се: $19 \%$

Свеједно ми је: $27 \%$

Уопште се не слажем: $9 \%$ Не слажем се: $18 \%$ 
- Предност учења латиничког писма у школама је лакше споразумевање са странцимма током живота.

У потпуности се слажем: $42 \%$ Слажем се: $25 \%$

Свеједно ми је: $16 \%$

Уопште се не слажем: 9\% Не слажем се: $8 \%$

- Саобраћајни знаџи обавештења треба да буду исписани на оба писма због лакиег сналажења туриста.

У потпуности се слажем: $55 \%$ Слажем се: $27 \%$

Свеједно ми је: $10 \%$

Уопште се не слажем: 5\% Не слажем се: $3 \%$

- Уколико бисмо латиничко писмо избацили из јавне употребе, употреба ћириличког писма би се драстично повећала.

У потпуности се слажем: $29 \%$ Слажем се: $27 \%$

Свеједно ми је: $19 \%$

Уопште се не слажем: 6\% Не слажем се: $19 \%$

- Употреба ћириличког писма у образовним институцијама би подстакла ученике/студенте да више негују свој језик и писмо.

У потпуности се слажем: 36\% Слажем се: $33 \%$

Свеједно ми је: $18 \%$

Уопште се не слажем: 6\% Н слажем се: $7 \%$

- Коришћење ћириличког писма на друштвеним мрежама помогло би промоцију наше културе код странацуа.

У потпуности се слажем: $32 \%$ Слажем се: $27 \%$

Свеједно ми је: $21 \%$

Уопште се не слажем: $11 \%$ Не слажем се: $9 \%$

- Табле са натписима улища треба да буду само на ћириличком писму да би подстакла страние да га науче.

У потпуности се слажем: $18 \%$ Слажем се: $10 \%$

Свеједно ми је: $22 \%$

Уопште се не слажем: $21 \%$ Не слажем се: $29 \%$ 
- Ћириличко писмо ће временом изгубити на својој вредности и престати да се користи у потпуности.

У потпуности се слажем: $23 \%$

Слажем се: $27 \%$

Свеједно ми је: $14 \%$

Уопште се не слажем: $13 \%$

Не слажем се: $23 \%$

- Регистарске таблице на аутомобилима би требале да буду на ћириличком писму.

У потпуности се слажем: $28 \%$

Слажем се: $10 \%$

Свеједно ми је: $27 \%$

Уопште се не слажем: $19 \% \quad$ Не слажем се: $16 \%$

- Коришћење латиничког писма при куцању СМС порука је практичније него коришћење ћириличког писма.

У потпуности се слажем: $37 \%$

Слажем се: $28 \%$

Свеједно ми је: $15 \%$

Уопште се не слажем: 8\%

Не слажем се: $12 \%$

- Друштвене мреже дају предност латиничком писму у односу на ћириличко.

У потпуности се слажем: $52 \%$

Слажем се: $32 \%$

Свеједно ми је: $8 \%$

Уопште се не слажем: $3 \%$

Не слажем се: $5 \%$

- У образовним институцијама треба да се користи и латиничко писмо због страних држављана који их похађају.

У потпуности се слажем: $39 \%$

Слажем се: $23 \%$

Свеједно ми је: $18 \%$

Уопште се не слажем: $11 \%$ Не слажем се: $9 \%$

- Латиничко писмо ће временом изгубити на вредности.

У потпуности се слажем: 9\%

Слажем се: $3 \%$

Свеједно ми је: $18 \%$

Уопште се не слажем: $44 \%$ Не слажем се: $26 \%$ 
- Латиничком писму треба дати предност у односу на ћириличко.

У потпуности се слажем: 6\%

Слажем се: $0 \%$

Свеједно ми је: $17 \%$

Уопште се не слажем: $56 \%$

Не слажем се: $21 \%$

\section{4. Закључак}

На основу анализе може се закључити да је употреба два писма у Шапцу веома распрострањена и општеприхваћена. У неким доменима живота може се, међутим, уочити да је употреба једног писма доминантнија у односу на друго.

Анализа прве групе питања упућује на закључак да је употреба ћириличког писма доминантнија у односу на латиничко у неким формалним ситуацијама као што су потписивање, попуњавање налога за уплату и сл. Истраживање показује да савремени начини комуникације, мисли се пре свега на комуникацију путем интернета и мобилних телефона, имају велики утицај на избор писма. На основу анализе резултата анкете уочава се да је латиничко писмо доминантније у односу на ћириличко при комуникацији путем друштвених мрежа и СМС порука. Анкета показује да највећи утицај на избор писма има унапред дефинисана латинична тастатура као иницијална на телефонима, као и навика испитаника, формирана пре него што је употреба ћирилице у овим доменима била могућа. Ови чиниоци утичу на знатно чешћу употребу латиничког писма када се ради о комуникацији путем СМС порука (88\% испитаника) и комуникацији путем друштвених мрежа (86\% испитаника). Иако велики број испитаника (84\%) зна да попут латиничког писма, постоји могућност коришћења и ћириличког писма, они се из наведених разлога, али и због комуникације са странцима на енглеском, шпанском или француском језику, махом опредељују за латиницу. Надаље, истраживање показује да испитаници нису у потпуности упознати са доменима службене употребе писма у нашој земљи, као и да не придају много пажње томе које се писмо у различитим ситуацијама користи. На овакав закључак упућују одговори у вези са већином питања из треће групе. Тако је, на пример, тек 10\% испитаника дало тачан одговор на питање којим писмом су исписане таблице на превозним средствима. Према члану 27 Правилника о регистрачији моторних и прикључних возила, таблице на превозним средствима исписане су на оба писма, јер поред латиничког 
натписа који заузима већи део, оне садрже и ћириличка слова којима се означава регистарско подручје. Највећу подељеност испитаника можемо видети на примеру питања којим писмом су исписани саобраћајни знаци „обавештења”. Да су ови знаци писани ћириличким писмом, мисли 18\%, а латиничким писмом 28\% испитаника, док је њих 29\% одговорило да нису сигурни. Само 25\% испитаника као одговор изабрало је оба писма, што је, према члану 11 Правилника о саобраћајној сигнализащији, тачан одговор. Такође, према истом члану прописана је употреба оба писма када говоримо о таблама са називима насељених места. Резултати наше анкете показују да је $56 \%$ испитаника дало тачан одговор, али је значајно велики број испитаника (32\%) као одговор изабрало ћириличко писмо, што се може сматрати погрешним одговором. На основу првог дела анкете уочава се постојање ставова испитаника да у одређеним сегментима живота употреба латиничког писма има предност у односу на ћирилицу, али у другом делу истраживања, када су се изјашњавали у вези са експлицитно исказаним тврдњама у вези са употребом писма, ситуација је донекле другачија.

Висок проценат испитаника забринут је за судбину ћирилице. Чак $72 \%$ сматра да се у савременом друштву не посвећује довољно пажње неговању и очувању ћирилице, а 50\% сматра да ће временом чак изаћи из употребе. Упркос томе, резултати анализе анкете показују да велики број испитаника подржава јавну и приватну употребу латиничког писма. С друге стране, 66\% испитаника не слаже са тим да латиничко писмо добије статус другог службеног писма.

Спроведено истраживање указује на став да у нашем друштву важно место имају оба писма. Ћириличко писмо испитаници схватају као важан део традиције и културе који треба неговати, али исто тако сматрају да латиничко писмо има значајну улогу у савременим свету, у међунационалној комуникацији и у савременим комуникацијским системима. Тако, на пример, $67 \%$ испитаника сматра да је предност учење латиничког писма у школама због могућности споразумевања са странцима током живота, као и став 57\% испитаника о корисности употребе оба писма, док само 14\% испитаника сматра да то говорницима српског језика не иде у прилог. Такође, са тврдњом да латиничко писмо представља културно благо ове земље и да је треба поштовати као и ћириличко слаже се 46\% испитаника. Ипак, мора се узети у обзир и чињеница да се $27 \%$ учесника у нашем истраживању није сложило са тим. 


\section{ЛИТЕР А Т У Р А}

Антонић, Ивана (1987). Употреба ћирилице и латинице у основним и средњим школама у Новом Саду. Прилози о проучавању језика, 23: 129-151.

Антонић, Ивана, Савић Свенка (1987). Писма у употреби. Кюижевност и језик. 3-4: 183-201.

Антонић, Ивана (1988). Употреба писама у приватним видовима комуникације (Резултати пилот истраживања у основним и средњим школама у СР Србији). Реферат на XII конгресу Савеза славистичких друштава Југославије, Нови Сад.

Антонић, Ивана (1989). Употреба писама у приватним видовима комуникације (Резултати пилот истраживања у основним и средњим школама у СР Србији). Свеске (Сарајево: Институт за проучавање националних односа). 26-27: 327-346.

Бугарски, Ранко (1996). Језик у друштву. Београд: Чигоја штампа.

Бугарски, Ранко (1997). Писмо. Београд: Чигоја штампа.

Бугарски, Ранко (2005). Језик и култура. Београд: Чигоја штампа.

Закон о службеној употреби језика и писма („Сл. гласник РС“, БР. 45/91, 53/93, 67/93, 48/94, 101/2005 - др. закон, 30/2010, 47/2018 и 48/2018 - испр.)

Пешикан, Митар, Јован Јерковић, Мато Пижурица (2010). Правопис српскога језика. Нови Сад: Матица српска.

Правилник о саобраћајној сигнализацији („Службени гласник РС”, број 85/17)

Устав Р. Србије <http://sllistbeograd.rs/documents/ustav_republike_srbije_cyr.pdf>

Шипка, Милан (2006). Језик и политика. Београд: Београдска књига

Antonić, Ivana (1989). The Usage of Two Alphabets in Private Communication. InterUniversity Centre (IUC) of postgraduate studies, Dubrovnik, course "Cognitive Linguistics", Jun 19 to 30, 1989.

Savić, Svenka, Ivana Antonić (1987). Use of Cyrillic and Latin Alphabets. The Second International Congress of Applied Psycholinguistics, Section Literacy, Kassel, July 27 to $30,1987$. 


\section{Srđan Đurić}

VIEWS OF THE USE LETTERS IN THE MUNICIPALITY SABAC

\section{SUMMARY}

The paper analyses the attitudes of citizens of Sabac municipality towards the use of Cyrillic and Latin alphabet. The aim of the research is to determine the attitudes towards the official and unofficial use of the two letters in modern Serbian language. The research is being conducted based on an anonymous survey. The results should show whether one letter has the advantage over the another one as well as what are the parameters that effect the choice of the letter use.

KEYWORDS: letter use, Cyrillic script, Latin script, sociolinguistics.

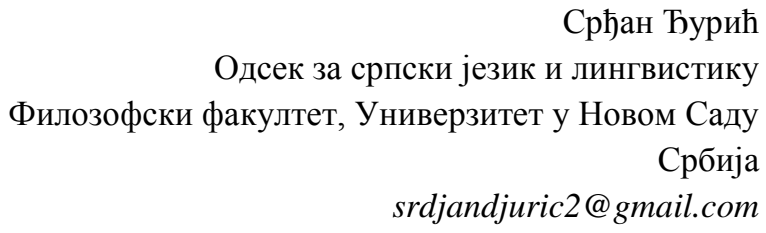

